\title{
DRUG ADDICTION. DRUGS AND THEIR EFFECTS ON MAN
}

\author{
Bocharova Inna Anatolevna \\ $\mathrm{PhD}$ in Biology, Associate Professor, Department of Biology, \\ Volgograd State University \\ innavova50@rambler.ru,bot@volsu.ru \\ Prospect Universitetsky, 100, 400062 Volgograd, Russian Federation
}

Agadzhanov Vadim Rubenovich

$\mathrm{PhD}$ in Medicine, Senior Research Woker, Associate Professor, Department of Biology,

Volgograd State University

agajanoff.vadim@yandex.ru,bot@volsu.ru

Prospect Universitetsky, 100, 400062 Volgograd, Russian Federation

Sagalaev Vadim Alexandrovich

DSc in Biology, Professor, Head of Department of Biology,

Volgograd State University

alex_sag@mail.ru,bot@volsu.ru

Prospect Universitetsky, 100, 400062 Volgograd, Russian Federation

\begin{abstract}
Some modern problems of drug addiction are represented in the article in generalized and brief form. There is an attempt to revile the peculiarities of most spread drugs, it is noted the link of certain drugs and criminal behaviour, the peculiarities of the drug developed dependence is underlined, the scheme of different drug addict groups and personal typology is showed, some social problems are mentioned, contemporary narcotic situation in Russia and it's dynamic for last decades is done, peculiarities in Volgograd region is reviled.
\end{abstract}

Key words: drugs, drug addiction, crime effect, stages of drug addiction, personal typological peculiarities, statistics of drug addiction.

At the last time the use of narcotics and their illegal trade has a catastrophic dimensions in much countries especially well development. The wide spread of drugs in the development countries may be the result of some social conditions, such as unemployment, uncertainty in the future, everyday stress situation, strong nervous and psychical strain, desire to get away from reality.

The aim of the investigation was an attempt to determine in common and brief form some complex problems of modern drug addiction. It's (2) tasks included the following: 1) to reveal the more spread form of drug addiction and those associated with crime behaviour; 2) to describe the stage of drug addiction; 3 ) to estimate the role of person drug intake typology and to analyze the contemporary narcotic situation in Russia and Volgograd region.

In many countries for the last 10 years along with consuming well known drugs there is increased the number of drug addicts consuming the psychotropic constituents. In such attitude amphetamine and hallucinogens may be considered as most dangerous. As it is indicated in the international antidrug centre 
in New York the common number of drug addicts in the world may be about many millions. Depend on their effects on man they may be delivered at 2 large groups: 1) with exiting effect, 2) with sedative effect. It is necessary to keep in mind that each of drugs has a lot of different hidden properties of effecting the nerve system. The common picture of the different drug effecting may be following. Thus, Indian hemp, leaves of coca, seeds of poppy are considered as most ancient natural drugs. Opium and its derivates such as morphine and heroine have an anesthetic affect and deliver the state of trouble and fear, diminish the filling of hunger and so on. The some similar effects have hashish and another derivates of the plant Cannabis sativa. Cocaine usually causes the exiting effect being often accompany with hallucinations and euphoria with some paranoid appearance. Sometimes this drug may stimulate violence and psychical activity of man $[1 ; 2]$.

In the sixties years of last century there is appear the new dangerous drugs such as D-lysergic acid, half synthetic substance of the product of lysergic acid that may induce hallucinations at the dose of one million part of the gram per one kilogram of wait.

Among the drugs which are most often associated with criminal behavior the investigators indicate the next categories: hallucinate, opiate, sedative and hypnotic substances. If don't pay attention the crimes, connecting with the spread and store of drugs most impotent problem may be the provocation by drugs the criminal effects especially of the violent character and the damage to the drug addicts health. The comparison of the role of such substances as cannabis, amphetamine, cocaine, heroin and alcohol (as represent of the group of sedative and drug substances) allowed to consider the last one to be most linked to violent crimes such as murder, brigand's attacks and so on $[3$, p. $341 ; 5 ; 12$, p. 205]. It is known that in the medium and large doses alcohol evidently has influence on the function of such brain structures that regulate the ability of self-control. Alcohol may also breaks the processes of information transformation that results the person to loose the opportunity to correct estimate of social stimulus and may not adequately react the real threat.

But it is rather probable that the aggressive behavior caused by alcohol is simultaneous influence of pharmacologic effects, cognitive waiting and situative factors $[3 ; 5]$.

The state of drug addicts is characterized by the next peculiarities: 1) the desire to go on to intake the drugs and to get them with all possible means; 2) intention to increase of dose; 3 ) appearance of dependence of psychical and physical character.

So named "syndrome of narcomania" is formed after occasional or systematic taking of drugs. The stages of this process may develop more quickly or slowly and consist mainly in the following:

1. Initial euphoria, which may be rather short. It is typical for certain drugs (especially such as opium and morphine).

2. Tolerance, which develops gradually and is explained by the decreasing of person reaction to the same dose of the substance, that lead to dose increasing.

3. Addiction, which is considered by the most of investigates as the appearance of both psychical and physical dependence and the last one is revealed in the classic symptoms of abstention or "syndrome of cessation" with heavy functional and organic disorders.

4. Abstention (syndrome of cessation) usually begins $12-48$ hours later last taking of drug and has the symptoms of nervous disorders, pulse rate increase, cramps, vomiting, salivation, and diarrhea and so on. Sometimes there may be such a dangerous symptom as collapse. The attack may be considered as a state of acute necessity of the drug that become the necessary factor of inner physiological processes [9, p. 285].

The person becomes a drug addict usually not once. Much depend on the personal individual characteristics and the type of the drug taking. In some cases the dependence on the vegetable and chemical preparations get almost from the first time and in others there are need month and even years. There are different opinions about the person drug taking typology each of which has rights to existence. Below the conclusions of one of the theories concerning the drug addicts personal 
peculiarities according to E.A. Babaian are represented [9]. In correspond with this conception the drug consumers may be divided into the next groups:

1. Experimenters. It is the most large of all groups including the persons who not return to drug taking after the first time.

2. Episode consumes. The persons who intake drugs mainly accidentally belong to this group. The intention to take the drugs out of these situations is absent.

3. System consumer. That is such persons who consume the drugs according to certain scheme, for instance on the case of birthday or on the case of receiving some results in the work and so on, considering that it will not influence there psychic and physiology.

4. Constant consumer. They are consistently formed of the first third groups and often have already psychical drug addiction that's why take the drug habitually.

5. Drug addicts patients. The individuals of that group frequently have physical dependence from drugs as well as psychical. At some estimations there are about 0.5 million and more drug addicts in Russia.

The first four groups are considered as behavioural ones and need in the first turn the tutor help but the fifth group is needed the qualified treatment as well as social rehabilitation [4, p. 12; $8 ; 10$, p. 42].

For the last period the number of narcotic dispensaries is 1.5 times less and number of bed places about 2.3 times, meanwhile the number of drug addicts are enlarged persistently. The serious obstacle for effective therapy of drug addict patients is the absence of the rehabilitation centers and departments for long time patients presents in the country. There is also a problem of not enough using the specially educated psychologists and sociologists in drug addict institutions.

In the middle of the twentieth century one of the most actual problem of Russia was dipsomania but later it had tendency to transform in the problem of drug consume. In Russia this problem concerns adults as well as children and the youth. The statistics of drugs consuming is not satisfactory in modern period. According to the information of Federal drug control service (FDCS) there are about 3 million persons of regular drug consuming in the country in 2012 but the experience of drug consuming have about 18 millions of persons. For the last ten years the mortality of addicts is ten times as large and the mortality of children is 45 times as large [6, p. 58]. The drug addiction in Russia grow young again and $84 \%$ of drug consumers confirm that they use drugs in the first time at the age of 15 years. The average lifetime of regular drug consuming persons is about 5 years and lifetime some of them is not more than 1 year. The peculiarities of the drug consuming in Russia may be considered as following: accessibility of drugs; enlargement of assortment of drugs; increasing of cocaine, heroin and synthetic drugs consumption; development of polynarcomania; adaptation to the country conditions; not effectiveness of the medical help to the drug consumers.

Besides it is interesting to analyze the situation in Russia associated with the sick rate of dipsomania, alcoholic psychosis and drug consumption for the long period (for instance during 1970-2009 years).

According to some literature sources the sick rate of the population of dipsomania and alcoholic psychoses per 100000 of men of population during the period of 19702009 years is as following [11]. In 2009 there are 2083 thousands of men ( 1468 persons per 100000 of population) registered with diagnoses of dipsomania and alcoholic psychoses. That is $15.5 \%$ less than in 1990 (or $11.7 \%$ less per 100000 persons of population). The most high indexes were registered in the middle of 1980th years 2.8 billions of persons (or 1959 persons per 100000 of population). Unlike of the tendency of moderate decreasing of the sick rate concerning the consumption of alcohol the number of persons registered with diagnose of narcomania and toxicomania is constantly increased. It is increased from 10.4 thousands of persons ( 8 per 100000 persons of population) in 1970 year to 355.6 thousands of persons (251 per 100000 of population) in 2009 (pict. 1, 2). 


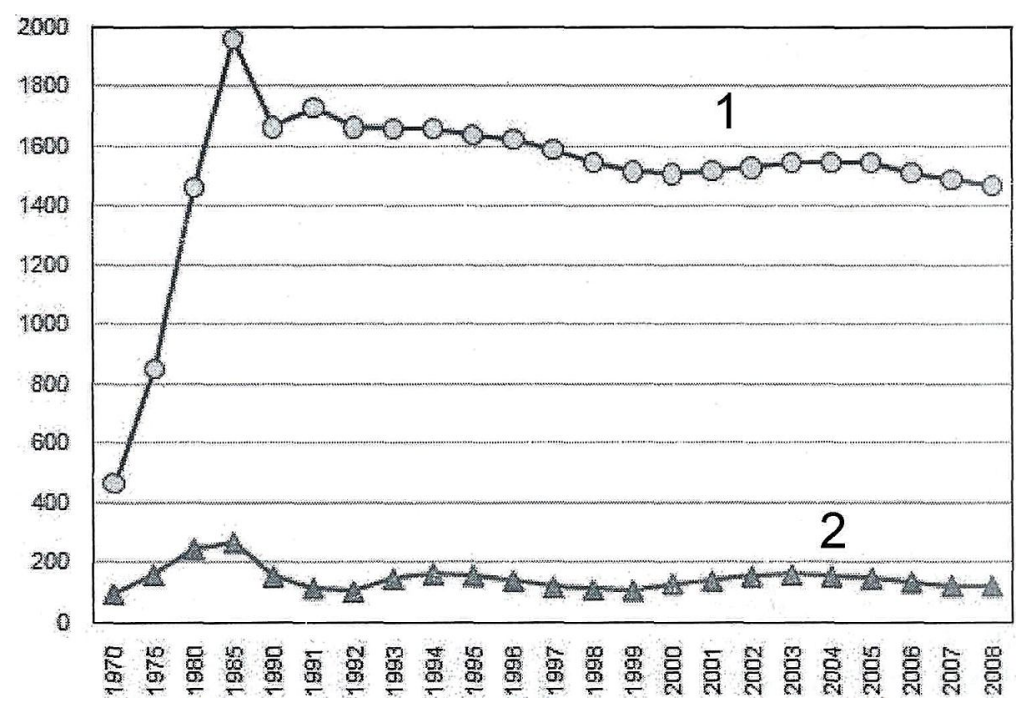

Pict. 1. Sick rate of dipsomania and alcoholic psychoses per 100000 persons of population during 1970-2009 years: 1 - being registered persons; 2 - first registered persons

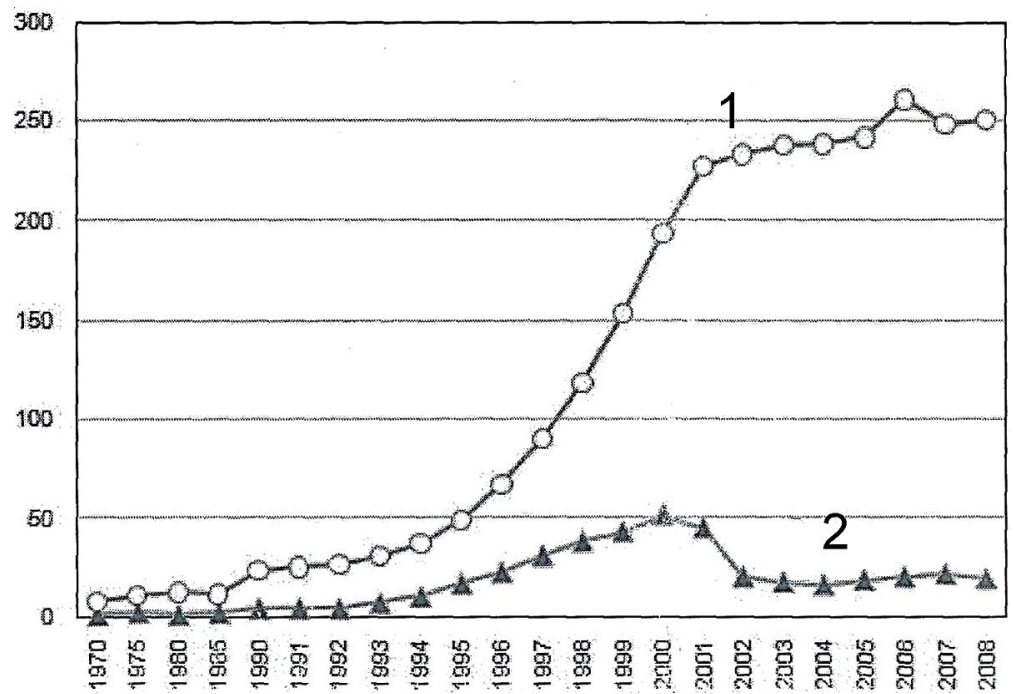

Pict. 2. Sick rate of drug addiction and toxycomania per 100000 persons of population during 1970-2009 years: 1 - being registered persons; 2 - first registered persons

A special attention may be paid to narcotic situation in some separate districts. For instance it may be one of districts of Volgograd region. So, in 2012 in Mihailovski district of Volgograd region there are 108 persons registered as drug consumers according to information of Mihailovsky department of FDCS. The main drug consumed here is a cannabis that is explained by the nature particularity of this region and the wide spread of this plant. The number of administrative delinquents connected with drug consume is increased every year. The main drug consumers are the mail persons at the age of 25-35 years being unemployed. The principle peculiarity of cannabis abuse are fixed by some investigators lately [7, p. 20].

For the last several years it is noticed the stabilization of narcotic situation here and number of persons registered as addicts is practically at the same level. 


\section{Conclusions}

Among the most wide-spread drugs must be mention opium and its derivates, than derivates of cannabis, cocaine and also psychostimulants and hallucinogens, especially products of lysergic acid. The comparison of such substances as cannabis, amphetamine, cocaine and alcohol allowed to consider the last one is most linked with violent crimes.

The main stages of drug addicts include: psychic addiction, tolerance, physic addiction and abstention.

The drug addicts according to personal peculiarities may be divided in next groups: experimenters, episode consumers, systematic consumers, constant consumers and drug addict patients. The first groups need in the first turn the tutor help but the lust one is needed the qualified treatment as well as social rehabilitation.

According to the last statistic dates (2012 year) there are about 3 million persons of regularly drug consumers in Russia. For the last ten years the mortality of addicts is ten times as large and their average lifetime is about 5-10 years. The sick rate of dipsomania and alcoholic psychosis for the last twenty years is decreased and sick rate of narcomania and toxicomania is increased. The narcotic situation in one of districts of Volgograd is described.

\section{REFERENCES}

1. Alcohol and drug dependence of teenagers. The ways of overwhelm / ed. by E. F. Vagner, H. B. Woldron. - Moscow : Academia, 2006. -415 p.
2. Balandin, A. The most dangerous drugs / A. Balandin, L. Balandina, V. Dganibecov. - Moscow : GrossMedia, 2008. -105 p.

3. Bushman, I. R. Effects of alcohol on Human Aggression : An Integrative Research Review / I. B. Bushman, H. M. Cooper // Psychological Bulletin. - 1990. - V. 107. - P. 341-354.

4. Chernyshova, V. N. Pedagogical prophylactic measures of drug addiction amongst pupils and students as social and pedagogical process /V. N. Chernyshova // Sociological education. - 2007. P. 11-16.

5. Effects of Alcohol and Self-awareness on Human Physical Aggression / D. S. Boley [et al.] // Personality and Social Psychology Bulletin. - 1983. P. 289-295.

6. Koshkina, E. A. Modern state of narcotic situation in Russia according the state statistic dates /E. A. Koshkina, V. V. Kirganova // Narcologi. - 2009. № 8. - P. 42-59.

7. Koshkina, E. A. The profile of Moscow population of cannabis consumer / E. A. Koshkina, E. N. Bobkov, V. V. Kirganova // Narcology. - 2013.№ 1. - P. 19-27.

8. Kozlov, A. A. The narcomanic person / A. A. Kozlov, N. L. Rochlina // G. of neurology and psychiatry. - 2000. - № 7. - P. 13-27.

9. Narcology : text book / ed. by A. Babajan, M. Gonopolskij. - Moscow : Medicina, 1990. 304 p.

10. Pljushch, I. V. The objects of prophylactic measures of taking of psychic active substances in educative environment / I. V. Pljushch // Bases of life activity security. -2008 . - № 4. - P. 41-52.

11. Shcherbakova, E. Russian demographic barometer / E. Shcherbakova // Demoscop weekly. 2010. - № $418-$ P. 6-8.

12. Volkov, V. N. Legal psychiatry. The course of lectures / V. N.Volkov. - Moscow: Jurist, 1998. -408 p. 


\section{НАРКОМАНИЯ. НАРКОТИКИ И ИХ ВЛИЯНИЕ НА ОРГАНИЗМ ЧЕЛОВЕКА}

\section{Бочарова Инна Анатольевна}

Кандидат биологических наук, доцент кафедра биологии Волгоградского государственного университета innavova50@rambler.ru, bot@volsu.ru Проспект Университетский, 100, 400062 г. Волгоград, Российская Федерация

\section{Агаджанов Вадим Рубенович}

Кандидат медицинский наук, старший научный сотрудник, доцент кафедры биологии Волгоградского государственного университета agajanoff.vadim@yandex.ru, bot@volsu.ru Проспект Университетский, 100, 400062 г. Волгоград, Российская Федерация

\section{Сагалаев Вадим Александрович}

Доктор биологических наук, профессор, заведующий кафедрой биологии Волгоградского государственного университета alex_sag@mail.ru, bot@volsu.ru Проспект Университетский, 100, 400062 г. Волгоград, Российская Федерация

Аннотация. В статье в обобщенной и сжатой форме изложены некоторые сложные проблемы современной наркомании. Освещены особенности воздействия наиболее распространенных наркотических веществ, отмечена связь некоторых из них с проявлениями преступности, подчеркнуты особенности возникающей наркотической зависимости, показана взаимосвязь с типологическими особенностями личности, обозначены отдельные социальные проблемы, проанализирована современная наркоситуация в России, ее динамика за последние десятилетия, особенности в Волгоградской области.

Ключевые слова: наркотики, наркотическая зависимость, связь с преступными действиями, проявления наркомании, типологические особенности личности, статистика наркопотребления. 